\title{
RECURRENT SEVERE HEPATITIS OF AUTOIMMUNE ORIGIN
}

\section{Gregor Krstevski ${ }^{1}$, Viktorija Caloska Ivanova ${ }^{1}$, Vladimir Andreevski ${ }^{1}$, Vladimir Serafimovski ${ }^{2}$}

\author{
${ }^{1}$ University Clinic of Gastroenterohepatology, Faculty of Medicine, University Ss. Cyril and Methodius, Skopje, RN Macedonia \\ ${ }^{2}$ Macedonian Academy of Sciences and Arts, Skopje, RN Macedonia
}

Corresponding author: Viktorija Caloska, University Clinic of Gastroenterohepatology, Faculty of Medicine, University Ss. Cyril and Methodius, 1000 Skopje, RN Macedonia; E-mail: viktorijacaloska@gmail.com

\begin{abstract}
The autoimmune liver disease constituent conditions include autoimmune hepatitis, primary biliary cholangitis, primary sclerosing cholangitis and IgG-4 associated cholangitis. They remain a diagnostic challenge to the practicing physician due to their close resemblance in clinical course, and laboratory and imaging findings to the vast array of other etiologies of liver injury. We report a case of recurrent severe hepatitis of autoimmune origin in a female patient. The disease course was marked by initial onset at age 39, followed by nearly four years of remission, and a second flare with a more exaggerated severity. Systemic lupus erythematosus was initially deemed as the culprit, however formal diagnostic criteria were not fulfilled and the serological findings were not reproduced at a later date. With the aim of ascertaining the underlying process, the patient underwent an extensive array of testing with regards to infectious, genetic, systemic and autoimmune disease. Positive anti-dsDNA (double stranded DNA) and an antinuclear antibody titer of 1:160 provided the strongest support for an autoimmune etiology, specifically autoimmune hepatitis or possibly an overlap syndrome. An excellent outcome was achieved via treatment with corticosteroids, ursodeoxycholic acid and plasmapheresis.
\end{abstract}

Keywords: autoimmune, hepatitis, autoantibodies

\section{INTRODUCTION}

Autoimmune liver disease (AILD) encompasses autoimmune hepatitis (AIH - previously lupoid hepatitis), primary biliary cholangitis (PBC - previously primary biliary cirrhosis) and primary sclerosing cholangitis (PSC). It is a group of immune mediated conditions that result in hepatocyte and bile duct destruction [1]. IgG-4 associated cholangitis (IAC) may also be placed in this group as a distinct entity, although key features of its pathophysiology remain unclear [2]. Estimates state a worldwide incidence rate of each of the autoimmune liver diseases of 1-2 per 100,000 population per year. There appears to be a general increase in the number of diagnosed cases within the last 30 years, and regional variations exist with a higher rate of $\mathrm{PBC}$ seen in Great Britain and Scandinavia. However, the limited number of population studies make it difficult to draw firm conclusions [1, 3]. Because onset, severity and disease course closely resemble the immense multitude of other etiologies of liver injury, the diagnosis of the AILD constit- 
uent conditions remains a diagnostic challenge. High clinical suspicion and a targeted diagnostic approach are crucial in timely detection and treatment [1].

\section{CASE REPORT}

We present a case of recurrent severe hepatitis of autoimmune origin in a 39 year-old female. The patient, F. L., initially complained for fever, night sweats, pedal and hand edema, and yellow discoloration of the skin and eyes in November 2015. The symptoms had begun four months prior and had progressively worsened. Past medical history was only significant for H. Pylori infection treated with triple drug eradication therapy a year prior, as well as an artificial abortion (gravida 2, para 1) at approximately the same time. At symptom onset she had begun taking symptom targeted OTC drugs, however she denied use of any drugs or substances in doses known to cause liver damage, and did not consume alcohol. She reported an allergy to ketoprofen and analgin (metamizole). The physical examination revealed fever, skin and scleral icterus, enlarged anterior cervical lymph nodes, and an enlarged liver palpable two finger breadths below the right costal margin. Lab workup revealed a microcytic anemia, elevated transaminases (AST $1152 \mathrm{U} / \mathrm{L}$, ALT $462 \mathrm{U} / \mathrm{L}$ ) and a predominantly conjugated hyperbilirubinemia (total $116 \mathrm{umol} / \mathrm{L}$, direct $103 \mathrm{umol} / \mathrm{L}$ ). Abdominal ultrasound showed hepatomegaly, splenomegaly and a small amount of subhepatic ascites. CT abdomen did not confer any additional findings, and histopathology of a liver biopsy specimen noted findings in correlation with hepatitis from SLE. The serology was positive for anti-ssDNA antibody (35.64IE/ml, ref. $<20)$, anti-dsDNA antibody and ANA titer of 1:160, while it was negative for anti-LC-1 (liver cytosol type 1), anti-M2-3E (mitochondrial), anti-SLA/LP (soluble liver antigen/ liver pancreas), LKM-1 (liver kidney microsomal type 1) and PM-scl (exosome) antibodies. A diag-

\begin{tabular}{|l|l|l|l|}
\hline \multicolumn{4}{|l|}{ Table 1. Pertinent lab and imaging findings on admission of second hospital stay. } \\
\hline Analysis (units) & Result (Ref.) & Analysis (units) & Result (Ref.) \\
\hline Erythrocytes [10^12] & $4.47(4.2-5.5)$ & Total bilirubin [umol/L] & $195(<20.5)$ \\
\hline Hemoglobin [g/L] & $122(120-180)$ & Direct bilirubin [umol/L] & $155(<6.8)$ \\
\hline $\begin{array}{l}\text { Mean Corpuscular Volume } \\
\text { [fL] }\end{array}$ & $78(82-98)$ & Indirect bilirubin [umol/L] & $40(<13.6)$ \\
\hline Leukocytes [10^9] & $6.0(4-9)$ & AST [U/L] & $966(10-34)$ \\
\hline Platelets [10^9] & $153(150-400)$ & ALT [U/L] & $921(10-45)$ \\
\hline C-reactive protein [mg/L] & $42.6(<6)$ & Alkaline Phosphatase [U/L] & $400(36-126)$ \\
\hline ESR [mm/h] & $36(<20)$ & GGT [U/L] & $253(9-64)$ \\
\hline Sodium [mmol/L] & $130(137-145)$ & LDH [U/L] & $828(<248)$ \\
\hline Potassium [mmol/L] & $3.5(3.8-5.5)$ & Alpha-amylase (s) [U/L] & $25(30-110)$ \\
\hline Calcium [mmol/L] & $1.9(2.1-2.6)$ & Lipase [U/L] & $23(0-160)$ \\
\hline Creatinine [umol/L] & $49(45-109)$ & Iron (s) [umol/L] & $8.0(11.6-31.4)$ \\
\hline Urea [mmol/L] & $2.4(2.7-7.8)$ & Ferritin [pmol/L] & $833.65(591)$ \\
\hline Total protein [g/L] & $53(63-83)$ & Triglycerides [mmol/L] & $3.1(0.7-1.7)$ \\
\hline Albumin [g/L] & $27(35-50)$ & Cholesterol [mmol/L] & $5.1(3.6-5.2)$ \\
\hline Globulin [g/L] & $28(27-35)$ & Creatine Kinase [U/L] & $23(25-192)$ \\
\hline Prothrombin time[sec] & $19.7(9.8-14.2)$ & CK-MB [U/L] & $28(5-25)$ \\
\hline INR & $1.88(0.7-1.2)$ & Glucose [mmol/L] & $4.2(3.9-6.1)$ \\
\hline aPTT [sec] & $30.7(27.9-37.7)$ & Urine bilirubin & $+++(-)$ \\
\hline D-dimer [ng/mL] & $1522(0-500)$ & & \\
\hline $\begin{array}{l}\text { Abdominal ultrasound: Cirrhoticaly altered liver, diffusely enlarged with hyperechogenic parenchyma. } \\
\text { Portal vein dilated with no impediment to flow. A few small lymph nodes up in the liver hilum and para } \\
\text { aortic area are seen. No ascites. }\end{array}$ & \\
\hline $\begin{array}{l}\text { Legend: INR - international normalized ratio. } \\
\text { aspartate aminotransferase. ALT- alanine aminotransferase. GGT - gamma-glutamyltransferase. LDH - } \\
\text { lactate dehydrogenase. s - serum. }\end{array}$ & & \\
\hline
\end{tabular}


nosis of an active chronic hepatitis, systemic lupus erythematosus was made at the time, and the patient was treated with azathioprine and pulse doses of methylprednisolone. Improvement in the patient's condition and lab trends were observed and she was discharged three weeks later on dual oral maintenance immunosuppressive therapy. Checkup appointments revealed steady improvement and the follow-up with a rheumatologist revealed elevated antiTPO and TG antibodies with normal TSH, and negative ANA Hep 2 and ANA screen. These findings did not confer fulfillment of formal diagnostic criteria for SLE. A period of nearly 4 years of remission ensued. In September 2019 she again presented with a ten-day history of fever, fatigue, sleepiness, vomiting, yellow discoloration of the skin and eyes, and pain in the right upper abdomen. She reported non-adherence to her therapy at the time of symptom onset. On admission physical examination revealed altered mental status, fever, skin and scleral icterus, an enlarged liver, and tenderness to palpation in the right upper abdomen. Pertinent findings on admission are summarized in table 1 .
Parenteral corticosteroid treatment was initiated, and four sessions of plasmapheresis were performed via a femoral central venous catheter due to bilirubin levels of over $700 \mathrm{umol} / \mathrm{L}$. The CVC was removed due a catheter associated infection. Azathioprine was also shortly introduced and stopped due to cytopenia. During the hospital stay, the patient was also treated with supportive measures, LOLA, UDCA, LMWH, and substituted accordingly with albumin and FFP. Serial abdominal ultrasound exams showed largely consistent and unchanged findings. Due to nonadherence on the patient's part, magnetic resonance imaging was not successfully obtained. Figure 1 depicts the chronology of treatment and its relationship with lab trends.

Pertinent findings of the extensive array of analyses are summarized in table 2 .

Following eleven weeks of inpatient treatment, the patient was discharged on prednisolone 20mg PO daily and UDCA $250 \mathrm{mg}$ PO 1+2. Subsequent follow up visits showed significant improvement with laboratory and imaging trends towards normal.

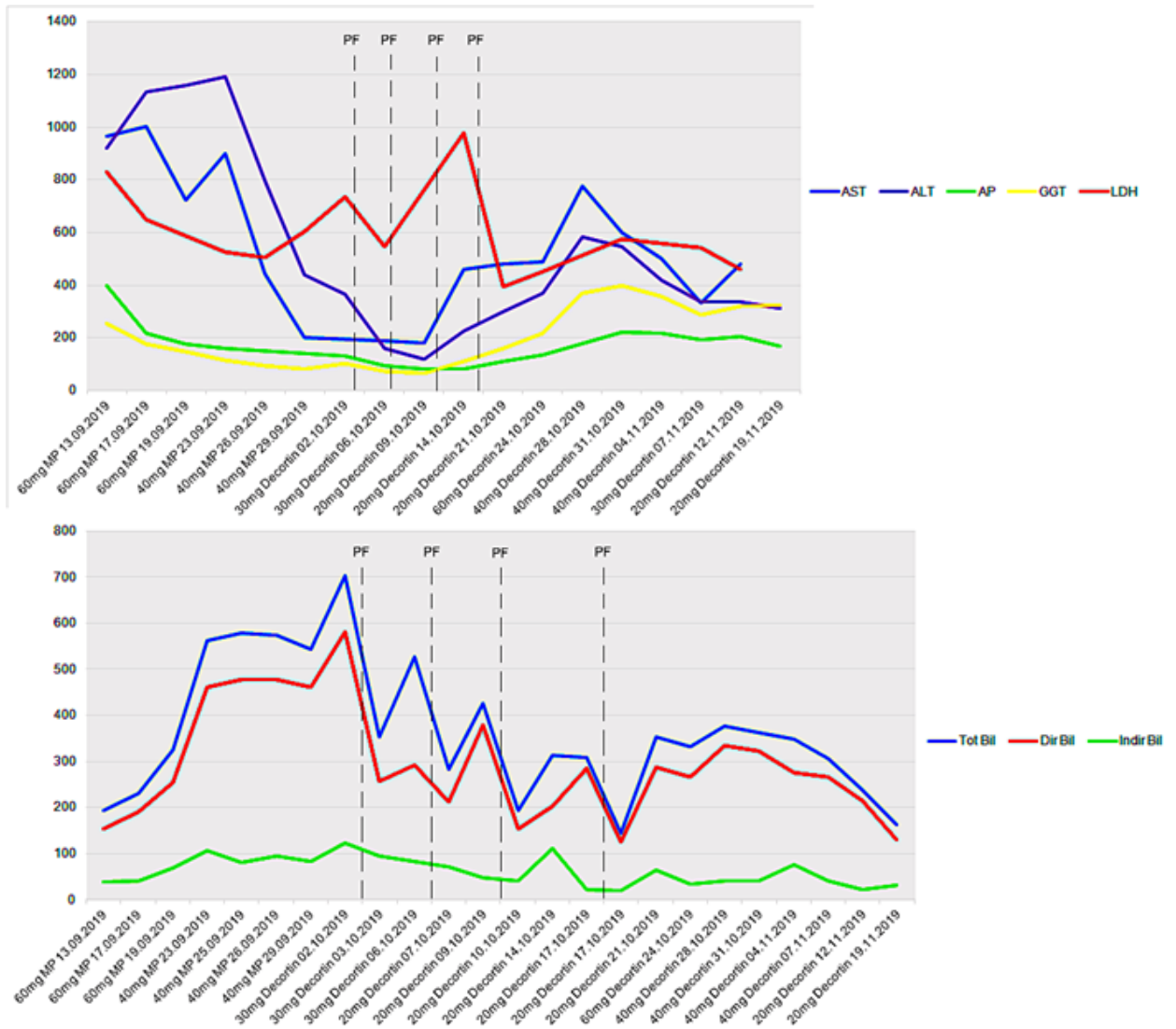

Fig. 1. A decline in transaminase activity (top) with corticosteroid treatment is seen. Steep drops in bilirubin levels (bottom) are noted with each session of plasmapheresis 


\begin{tabular}{|c|c|c|c|}
\hline Analysis (units) & Result (Ref.) & Analysis (units) & Result (Ref.) \\
\hline $\mathrm{CEA}[\mathrm{ng} / \mathrm{mL}]$ & $1.12(<5)$ & AFP $[\mathrm{ng} / \mathrm{mL}]$ & $3.6(<10)$ \\
\hline CA 19-9 [U/mL] & $167(<35)$ & CA $15-3[\mathrm{ng} / \mathrm{mL}]$ & $20.5(<35)$ \\
\hline $\operatorname{TgAb}[\mathrm{IU} / \mathrm{mL}]$ & $<20(<20)$ & CA $72-4[\mathrm{ng} / \mathrm{mL}]$ & $0.7(0.5-7)$ \\
\hline aTPO [IU/mL] & $41.9(<35)$ & Blood culture & $-(-)$ \\
\hline fT3 $[\mathrm{nmol} / \mathrm{L}]$ & $1.76(1.2-3.4)$ & Urine culture & $-(-)$ \\
\hline $\mathrm{fT} 4[\mathrm{pmol} / \mathrm{L}]$ & $15.6(10.3-24.5)$ & Leishmania & $\operatorname{IgG} / \operatorname{IgM}-(-)$ \\
\hline $\mathrm{TSH}[\mathrm{mU} / \mathrm{L}]$ & $1.02(0.5-4)$ & Leptospira & IgG/IgM - (-) \\
\hline $\operatorname{IgM}[\mathrm{g} / \mathrm{L}]$ & $4.4(0.4-2.5)$ & $\mathrm{HSV}$ & $\operatorname{IgM}-(-)$ \\
\hline $\operatorname{IgG}[\mathrm{g} / \mathrm{L}]$ & $12.2(6-16)$ & Hantaan virus & $\operatorname{IgG} / \operatorname{IgM}-(-)$ \\
\hline $\operatorname{IgA}[\mathrm{g} / \mathrm{L}]$ & $4.3(0.8-3.0)$ & Brucellosis & $-(-)$ \\
\hline Complement C3 [g/L] & $1.39(0.8-1.6)$ & HIV & $-(-)$ \\
\hline Complement $\mathrm{C} 4[\mathrm{~g} / \mathrm{L}]$ & $0.15(0.15-0.48)$ & anti-HCV & $-(-)$ \\
\hline Anti-dsDNA & $-(-)$ & anti-HAV IgM & $-(-)$ \\
\hline Anti-Smith & $-(-)$ & anti-HBc IgM & $-(-)$ \\
\hline Anti-SSA & $-(-)$ & HBsAg & $-(-)$ \\
\hline Anti-SSB & $-(-)$ & anti-HBs [mIU/mL] & $0.68(<5)$ \\
\hline Anti-cardiolipin IgG & $-(-)$ & Ceruloplasmin [mg/mL] & $0.81(0.2-0.6)$ \\
\hline \multicolumn{4}{|c|}{ Pneumoslide panel: Adenovirus IgG +/-. M. pneumoniae IgM +/-. Other negative (-) } \\
\hline \multicolumn{4}{|c|}{$\begin{array}{l}\text { Genetic testing: Wilson's disease - deletions and duplications on exons of the ATP7B gene are not } \\
\text { present. Genetic testing for benign recurrent intrahepatic cholestasis and familial intrahepatic cholestasis } \\
\text { - negative. }\end{array}$} \\
\hline \multicolumn{4}{|c|}{$\begin{array}{l}\text { Histopathology from liver biopsy: } \\
\text { (1) } 18.09 .2019 \text { : Chronic active hepatitis. Periportal spaces with morphologic signs for chronic biliary } \\
\text { stasis and abundant inflammatory infiltrate. Knodel score } 3 \text { (inflammation 3, fibrosis 0, piecemeal necrosis } \\
\text { 0) } \\
\text { (2) } 01.11 .2019 \text { : Liver parenchyma consisting of hepatocytes with emphasized intracellular and canalicular } \\
\text { cholestasis. Portal and periportal with multiplied connective tissue with light ductal reaction and moderate } \\
\text { mixed inflammatory infiltrate which expands into the surrounding liver parenchyma, focally with } \\
\text { destruction of single hepatocytes (interface hepatitis). Corresponds with cholestatic hepatitis. }\end{array}$} \\
\hline \multicolumn{4}{|c|}{$\begin{array}{l}\text { Peripheral blood smear: Erythrocytes without abnormal findings. Platelet aggregates seen in 2-3 fields. } \\
\text { Neutrophils with moderate, toxic granules. }\end{array}$} \\
\hline \multicolumn{4}{|c|}{$\begin{array}{l}\text { Legend: CEA - carcinoembryonic antigen. AFP - alpha fetoprotein. CA - cancer antigen. TgAb - } \\
\text { thryoglobulin antibody. aTPO - anti-thyroid peroxidase. fT3 - free triiodothyronine. fT4 - free thyroxine. } \\
\text { TSH - thyroid stimulating hormone. dsDNA - double stranded DNA. Anti-SSA - anti sjogren's syndrome } \\
\text { related antigen A. Anti-SSB - anti sjogren's syndrome related antigen B. HSV - herpes simplex virus. HIV } \\
\text { - human immunodeficiency virus. HCV - hepatitis C virus. HAV - hepatitis A virus. HBc - hepatitis B core. } \\
\text { HBsAg - hepatitis B surface antigen. }\end{array}$} \\
\hline
\end{tabular}

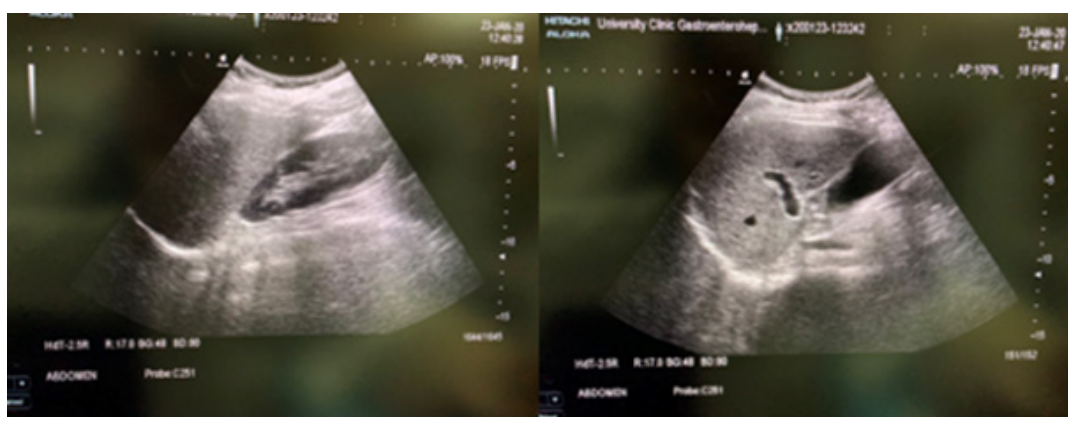

Fig. 2. Improvement noted on liver ultrasound performed two months after discharge 


\section{DISCUSSION}

In summary, this case describes recurrence of severe hepatitis with markedly elevated bilirubin levels, transaminases and a concomitant febrile state. Based on the episodes' similarity in onset, clinical manifestation and response to treatment, it can be concluded that both flares are the result of the same underlying pathologic process. The case's ambiguity warrants a broad differential approach.

Approximately 900 drugs, toxins and herbs are known to be toxic to the liver. The mechanism of damage is roughly classified in direct (intrinsic) and immune mediated (idiosyncratic). The clinical manifestation can vary significantly in terms of severity, laboratory values and time of onset since exposure. Therefore, the possibility of a toxic precipitant cannot be excluded with certainty despite the negative history in this regard [4]. As for infectious causes of liver damage, the viral hepatitides occupy a central role. Other causative agents include EBV, CMV, HSV, S. typhi, M. tuberculosis, Brucella spp, C. burnetii, Leptospira and other spirochetes, schistosomiasis, malaria, Candida spp. and $\mathrm{H}$. capsulatum. The extensive tests performed rule out an infectious cause [5]. Moreover, the patient did not consume alcohol. She also did not display any features of metabolic syndrome (obesity, diabetes melitus, hypertension), and intracellular fat droplets were not described on histopathology. Both alcoholic hepatitis and non-alcoholic steatohepatitis were thus ruled out [6].

With regard to the inherited conditions, genetic analysis distinctly ruled out Wilson's disease, as well as the BRIC and FIC disease spectrum. Furthermore, iron deposition in hemochromatosis results in skin hyperpigmentation, hypogonadism, diabetes mellitus, and characteristic histopathology. All of these elements were absent, and the serum iron was low, thereby making this diagnosis unlikely even in the presence of elevated ferritin. Alpha-1-antitrypsin deficiency was also considered unlikely in the absence of respiratory complaints. Numerous other inherited conditions, such as Rotor syndrome, Dubin Johnson syndrome and glycogen storage diseases affect the pediatric population, and do not correspond with the age of onset of symptoms in this case [7].
An array of systemic conditions can cause liver damage. They include ischemic hepatitis, congestive hepatopathy, numerous hematologic conditions, hyperthyroidism, adrenal insufficiency, hypercortisolism as well as sepsis, sarcoidosis, amyloidosis and metastases [8]. The constellation of the physical exam, imaging and laboratory results did not confer a suspicion of the aforementioned conditions. Connective tissue diseases require special consideration as serology and histopathology during the first admission pointed to hepatitis caused by SLE. It is at this point noteworthy that elevated ANA titers are also indicative of autoimmune hepatitis. ANA positivity was not subsequently reproduced, and per rheumatology formal criteria for SLE were not fulfilled. A 1984 study by R. Weisbart and K. Colburn looked at the effects of corticosteroids on antinuclear antibodies. They detected an average $43 \%$ reduction in antinuclear antibodies, including anti-dsDNA and anti-ssDNA following initiation of treatment with corticosteroids. This may explain the patient's subsequent seronegative status [9].

A 2012 publication by Juan-Manuel Anaya et al. discusses the concept of autoimmune tautology, which refers to autoimmune diseases' shared genetic factors, pathophysiological mechanisms, and common clinical signs and symptoms. They postulate that the cornerstone of autoimmune tautology is polyautoimmunity [10]. The same author defines polyautoimmunity in a 2014 review as more than one autoimmune disease existing in a single patient. He goes on to provide evidence that polyautoimmunity is seen in SLE, autoimmune liver disease and autoimmune thyroid disease, among others [11]. In our case, the patient had elevated autoantibodies to thyroglobulin and TPO, while TSH and fT4 were normal. A recent 2019 study by Siriwardhane et al. followed euthyroid subjects for 2 years and determined that $73 \%$ of subjects who developed hypothyroidism (group A1) and $68.6 \%$ of subjects who developed hyperthyroidism (group A2) actually had elevated aTPO long before the onset of thyroid dysfunction [11]. This groundbreaking finding infers that individuals with elevated aTPO may develop thyroid dysfunction in the future, even if they are initially euthyroid. This may very well prove to be true for our patient. Looking at our patient's elevated thyroid autoantibodies as potential predictors of future thyroid dysfunction through the lens of the autoimmune tautology, provides further support for the hypothesis of an autoimmune etiology of our patient's liver dysfunction. 
As previously noted, autoimmune liver diseases encompass $\mathrm{AIH}, \mathrm{PBC}$, PSC, and IAC. Overlap syndromes occur when criteria for diagnosis of more than one of these conditions are fulfilled. Unifying characteristics include a predisposing genetic susceptibility and poorly understood precipitating environmental and infectious triggers [13]. AIH mainly involves immune mediated inflammatory destruction of hepatocytes. It is more common in females, typically presents with an LFT pattern of parenchymal damage, and an elevated IgG. ANA (antinuclear antibody) and ASMA (anti-smooth muscle antibody) are characteristic for type I AIH, LKM1 (liver kidney microsomal type 1 antibody) are typical of type II, and anti-SLA (soluble liver antigen) are found in type III AIH. There is also an established association with HLA A3, B8, DR3, and DR4 haplotypes. T lymphocytes, NK cells and macrophages all play important parts in the disease process, and the condition is notoriously associated with other concomitant autoimmune diseases. Histopathology findings typically describe an interface and lobular necroinflammatory hepatitis with prominent plasma cells. First line treatment is with corticosteroids and azathioprine. The prognosis is poor in absence of response to treatment within the first 7-14 days, while achieving remission is associated with a 10 year prognosis greater than $90 \%$. Regular screening for hepatocellular carcinoma is warranted in these patients $[1,13,14]$. $\mathrm{PBC}$ is also more common in females over 40 years of age. It involves chronic cholestasis with progressive non-suppurative bile duct inflammatory destruction. LFT patterns are thus predominantly cholestatic, and accompanied by an $\operatorname{IgM}$ elevation. Autoantibodies typically found in PBC are AMA (antimitochondrial antibody), anti gp210 (glycoprotein 210) and anti sp-100. Histopathology reveals ductal and periductal inflammatory lesions, with possible granulomatous inflammation in later stages. Ursodeoxycholic acid is the first line therapy, and no other single agent has been found to be beneficial. Pruritus is common in PBC and can initially be approached with a bile acid resin such as cholestyramine. A 90\% 10 -year transplant free survival rate is observed in patients who after one year of treatment show normal bilirubin, and AST and alkaline phosphatase within 1.5 times the upper limit of normal [1, 13, 14]. PSC in essence involves chronic cholestasis with intra and extrahepatic bile duct inflammation and fibrosis. It is more commonly found in males and manifests with a predominantly cholestatic liver function test pattern. IgG and IgM immunoglobulin fractions are often elevated, and there is a clear association with inflammatory bowel disease (UC > Crohn), as well as elevated pANCA. Cholangiography shows focal bile duct dilation with multiple strictures in a beaded pattern, which can be treated via ERCP. MRCP has an excellent diagnostic value, and when characteristic findings are observed, liver biopsy is not necessary. Histopathology describes fibrosis and obliteration of large bile ducts, with progressive ductopenia. At this time, numerous regimens combining corticosteroids and UDCA have been proposed, however targeted treatment remains lacking. There is an increased risk of biliary sepsis, cholangiocarcinoma, gallbladder cancer and in those with IBD colon cancer [1, 13-15]. IAC is closely associated with autoimmune pancreatitis, and belongs to the broader IgG-4 related disease spectrum. Elderly males are often affected, and the onset may be precipitated by long term exposure to industrial chemicals. Pathophysiology is thought to involve pancreaticobiliary immune-mediated inflammation. Obstructive jaundice, abdominal pain and pancreatic involvement are typical clinical features. Imaging often demonstrates mass or sclerosing biliary lesions, which are frequently misdiagnosed as tumors. Liver function tests reveal elevated markers of cholestasis, accompanied by an increase in CA-19-9, however studies have shown that CA-19-9 can be elevated in a number of non-malignant liver conditions [16]. IgG-4 is diagnostic when elevated four times the upper limit of normal. Histopathology of bile duct and liver biopsy specimens exhibit characteristic infiltration with IgG-4+ B cells, CD4+ T lymphocytes and plasma cells, as well as obliterative phlebitis and advanced storiform pattern fibrosis. Corticosteroids are the cornerstone of treatment and have been demonstrated to yield an excellent outcome and prognosis $[1,2,13]$. In applying the aforementioned principles to the case at hand, it is evident that a varying degree of supporting evidence is present for each of the AILDs. It is important to note that all of the described conditions can progress to fulminant hepatic failure even with optimal treatment, in which case liver transplant is necessary [1, 13-15]. With regards to plasmapheresis as a treatment modality, Keklik et al. (2013) reviewed 11 patients with severe hyperbilirubinemia treated with plasma exchange and observed a statistically significant decline in bilirubin levels post procedure. They suggested that the approach serves to open an opportunity for recovery and 
cure, and that it improves the rate of survival in those who have sufficient residual hepatic regenerative capacity. This is especially founded when considering the life threatening nature of severe hyperbilirubinemia [17].

\section{CONCLUSION}

The disease course, serology, histopathology and response to treatment, in combination with absent evidence for infectious, underlying systemic and inherited diseases, point to an autoimmune etiology of the patient's condition. Substantial evidence points to AIH or possible overlap, and this includes female gender, initial elevated ANA titer, LFT pattern indicating significant parenchymal involvement, treatment response, and histopathologic description of inflammatory infiltrates and interface hepatitis. As previously stated, corticosteroid treatment may have influenced the subsequent seronegative ANA status of the patient. Nonetheless, the available information does not permit definitive placement into the well-known and defined autoimmune liver diseases and overlap syndromes. Reassessment of autoantibodies and testing for additional antibodies, including but not limited to pANCA and anti-gp210 would be warranted to ascertain the exact disease process. MRCP and HLA haplotype testing may also provide some helpful information. Most importantly, a favourable result was achieved, and the treatment approach would have remained largely unaltered even with this information available.

\section{REFERENCES}

1. Than NN, Oo YH. A Concise Review of Autoimmune Liver Diseases. Pathogenesis, Clinical Aspects and Therapy of Specific Autoimmune Diseases. IntechOpen. 2015. DOI:10.5772/60520.

2. Hubers LM, Wenniger LJM, Doorenspleet ME. IgG-4 Associated Cholangitis: A Comprehensive Review. Clinic Rev Allerg Immunol 2015; 48, 198-206. DOI:10.1007/s12016-014-8430-2.

3. Jepsen P, Gronbaek L, Vilstrup H. Worldwide incidence of Autoimmune Liver Disease. Dig Dis 2015;33(supp12):2-12. DOI:10.1159/000440705.

4. Mehta N. Drug-Induced Hepatotoxicity. Medscape 2019; https://emedicine.medscape.com/ article/169814-overview.
5. Talwani R, Gilliam BL, Howell, C. Infectious Diseases and the Liver. Clin Liver Dis 2011; 15(1), 111-130. DOI: 10.1016/j.cld.2010.09.002.

6. Sharma B, John S. Nonalcoholic Steatohepatitis. StatPearls. Treasure Island: StatPearls Publishing 2020; https://www.ncbi.nlm.nih.gov/books/ NBK470243/.

7. Kumar A, Riley CA. Inherited Liver Diseases in Adults. West J Med 1995; 163(4), 382-386. PMCID:PMC1303145.

8. Shimizu, Y. Liver in systemic disease. World $J$ Gastroenterol 2008; 14(26), 4111-4119. DOI: 10.3748/wjg.14.4111.

9. Weisbart RH, Colburn K. Effect of Corticosteroids on Serum Antinuclear Antibodies in Mac. Immunopharmacology. 1984. 8(2): 97-101. DOI: 10.1016/0162-3109(84)90048-1. PMID: 6334672.

10. Anaya JM, Villarraga AR, Carrasco MG. The Autoimmune Tautology. Polyautoimmunity and Familial Autoimmunity to the Autoimmune Genes. Autoimmune Disease 2012; 2012. Article ID: 297193. DOI:10.1155/2012/297193.

11. Anaya JM. The diagnosis and clinical significance of polyautoimmunity. Autoimmun Rev 2014; 13(4-5):423-426. DOI:10.1016/j.autrev. 2014.01.049.

12. Siriwardhane T, Krishna K, Ranganathan V, et al. Significance of Anti-TPO as an Early Predictive Marker in Thyroid Disease. Autoimmune Diseases 2019; 2019. Article ID: 1684074. DOI:10.1155/2019/1684074.

13. Washington M. Autoimmune liver disease: Overlap and outliers. Modern Pathology 2007; 20(suppl 1): S15-30. DOI:10.1038/modpathol.3800684.

14. Trivedi PJ, Hirschfield GM. Treatment of autoimmune liver disease: current and future therapeutic options. Ther Adv Chronic Dis 2013; 4(3): 119-141. DOI: 10.1177/2040622313478646.

15. Goode EC, Rushbrook SM. A review of the medical treatment of primary sclerosing cholangitis in the 21st century. Ther Adv Chronic Dis 2016; 7(1): 68-85. DOI: 10.1177/2040622315605821.

16. Maestranzi S, Przemioslo R, Mitchell H. The effect of benign and malignant liver disease on the tumour markers CA19-9 and CEA. Ann Clin Biochem 1998; 35: 99-103. DOI: 10.1177/000456329803500113.

17. Keklik M, Sivgin S, Kaynar L. Treatment with plasma exchange may serve benefical effect in patients with severe hyperbilirubinemia: A single center experience. Transfusion and apheresis science: official journal of the World Apheresis Association: official journal of the European Society for Haemapheresis 2013; 48: 323-326 DOI: 10.1016/j.transci.2013.04.009. 


\section{Резиме}

\section{РЕКУРЕНТЕН ХЕПАТИТИС ОД ТЕЖОК СТЕПЕН СО АВТОИМУНО ПОТЕКЛО}

\section{Грегор Крстевски ${ }^{1}$ Викторија Чалоска ${ }^{1}$, Владимир Андреевски ${ }^{1}$, Владимир Серафимовски ${ }^{2}$}

${ }^{1}$ Универзитетска клиника за гастроентерохепатологија, Универзитет „Св. Кирил и Методиј“, Медицински Факултет, Скопје, РС Македонија

${ }^{2}$ Македонска академија на науките и уметностите, Скопје, РС Македонија

Автоимуните црнодробни заболувања вклучуваат автоимун хепатитис, примарен билијарен холангитис, примарен склерозантен холангитис и IgG-4 асоциран холангитис. Овие заболувања и понатаму претставуваат дијагностички предизвик поради сличноста во клиничката слика и лабораторискиот облик со мноштвото други етиологии на хепатално оштетување. Претставуваме приказ на случај на рекурентен хепатитис од тежок степен. Текот на болеста беше одбележан со иницијална презентација на 39-годишна возраст, приближно четиригодишен период на ремисија и втора потешка епизода. Првичните наоди беа сугестивни за ситемски лупус еритематозус, но критериумите за заболувањето не беа исполнети и резултатите не се реплицираа во подоцен датум. Се спроведоа исцрпни испитувања во правец на инфективни, генетски, системски и автоимуни заболувања, со цел утврдување на подлежниот патолошки процес. Автоимуната етилогија беше претпоставена како најверојатна поради позитвните anti-dsDNA антитела и ANA титар од 1:160. Наодите обезбедуваат најсилна поткрепа за дијагноза на автоимун хепатитис или преклопувачки синдром. Третманот со кортикотерапија, урзодезоксихолна киселина и плазмафереза резултираше со одличен клинички исход. Точниот патолошки процес останува нецелосно разјаснет и покрај исцрпните испитувања.

Клучни зборови: автоимун, хепатит, автоантитела 